\title{
RETROSPECTIVITY RECONSIDERED
}

\author{
T. KOOPMANS *
}

\section{The Prospectivity Problem}

IN its judgment of 8 April 1976, Defrenne v. Sabena, the Court of Justice of the European Communities gave an interpretation to the provisions of Article 119 of the E.E.C. Treaty, on equal pay of male and female workers, which caused some stir. ${ }^{1}$ The Court held that the equal pay rule had direct effect, in the sense that any female worker could appeal to it in proceedings against her employer before courts or tribunals of any of the Member States. This ruling embodied a novel interpretation of Article 119: not only because the Court itself had not yet applied its doctrine of direct effect to this article, but also because most of the authors on the subject had come to a different conclusion. ${ }^{2}$ The Court seems to have been aware of the practical problems which might result from such a situation; it added some considerations on what it called the "temporal effect " of its judgment. Its decision " might," it said, result in the introduction of claims by female workers dating back to the time when the direct effect of Article 119 came about (1963 for the "old " Member States!) ${ }^{3}$; therefore, it developed a certain number of reasons for deciding that "important considerations of legal certainty affecting all the interests involved" made it impossible to reopen the question as regards the past. Only workers who had already brought legal proceedings at the date of the judgment could benefit from the direct effect.

The European Court of Human Rights-the Strasbourg Courtrelied on this part of the Defrenne judgment when it had to consider whether Belgian legislation on the legal position of illegitimate children was contrary to certain provisions of the European Convention on Human Rights. In the Marckx case, it held that Belgium had actually violated the Convention by restricting rights of illegitimate children, such as inheritance rights, as compared to those enjoyed by legitimate children. ${ }^{4}$ However, the Court recognised

* Judge at the Court of Justice of the European Communities; 1965-78 Professor of Law, University of Leyden, Netherlands; 1976-77 visiting fellow commoner, Trinity College, Cambridge.

1 Case 43/75, Defrenne v. Sabena [1976] E.C.R. 481.

2 See, generally, O. Stocker, “ Le second arrêt Defrenne: l'égalité des rémunérations des travailleurs masculins et de travalleurs féminins," 13 Cah.Dr.Eur. 180 (1977).

3 See the text of Art. 119, par. 1, E.E.C.

- Eur.Ct. Human Rights, 13 June 1979, Marckx case, Series A, no. 31. 
that the Belgian Government had "an evident interest" in knowing what the "temporal effect" of its judgment would be. It referred explicitly to the Defrenne judgment in support of its conclusion that " the principle of legal certainty, which is necessarily inherent in the law of the Convention as in Community law, dispenses the Belgian State from reopening legal acts or situations that antedate the delivery of the present judgment."

The problem we should like to discuss concerns what both Courts call, in French-sounding English, the " temporal effect" of judicial rulings on the interpretation of existing law. It arises in cases in which a court gives a new interpretation to a certain rule of law, or to a legal principle (new as compared to its earlier case law, or new as compared to existing practice), and in which citizens, or business corporations, or administrative agencies, had no reason to foresee such a change. The question is then whether rulings of this kind should be considered as part of the rule of law they set out to interpret, and therefore apply retrospectively from the moment this rule of law came into force, or whether they should be considered as " new law," and therefore apply only to future cases. Framed in that way, the question presupposes that the normal system is one of retrospectivity, and this is in fact what most lawyers will take for granted. ${ }^{5}$ If a court interprets a legal provision, the interpretation it gives will normally be regarded as part and parcel of that provision since its inception; that means, in other words, that the effects of the judgment are retroactive, because the court, in applying its interpretation to the case at hand, implicitly assumes that it will apply the same interpretation to any case on the same problem-whether it arose before or after the court gave its interpretation, and whether it is based on facts occurring before or after that moment.

American legal authors give a more prominent place to our problem than their European colleagues. The "prospectivity debate" came in full swing in 1965, when the federal Supreme Court delivered its judgment in Linkletter v. Walker. ${ }^{6}$ The case concerned the "temporal effect" of a rule the Supreme Court had previously announced in one of its most strikingly innovating judgments on criminal procedure, Mapp v. Ohio. ${ }^{7}$ Mapp itself was more or less at the junction of two new lines of thought which had been gradually developed by the Supreme Court, the "exclusionary rule" and the " incorporation doctrine." The first of these was to the effect that the interdiction of unreasonable searches and seizures, included in

5 See, among others, D. Wyatt, " Prospective effect of a holding of direct applicability" [1976] E.L.Rev. 399.

- Linkletter v. Walker, 381 U.S. 618 (1965).

7 Mapp v. Ohio, 367 U.S. 643 (1961). 
the American Bill of Rights, ${ }^{8}$ implied that evidence obtained in violation of it could under no condition contribute to the conviction of the suspect. The second doctrine extended the guarantees provided for by the federal Bill of Rights to cases arising under state law, on the basis of the constitutional provision that no state shall “deprive any person of life, liberty and property without due process of law" " - which meant, according to the court, that safeguards to be respected by the states should be comparable, or even identical, to those imposed on federal authorities by the Bill of Rights. The importance of this " incorporation doctrine" was of course that the safeguards to be respected by the state consisted of constitutional provisions as interpreted by the federal Supreme Court, as the Mapp case was to show. It concerned the question whether the exclusionary rule applies to a state case, if the law of the state expressly denies that rule. The court had no difficulty in finding reasons for an affirmative answer ${ }^{30}$; it thereby handed down one of the most famous, but also one of the most debated, decisions of the Warren Court.

After Mapp was delivered, Mr. Linkletter attacked his conviction, allegedly obtained on the basis of illegal evidence; he did so not on direct review, his conviction being final, but by means of collateral attack (in the American systems of criminal procedure, the convict has frequent occasions to challenge his conviction). The Supreme Court inferred from this situation that the convict sought a retroactive benefit from a newly announced rule; it thought, however, that retroactivity was not a necessary consequence of such a new rule. Therefore, it said, it had to look at the exigencies of the situation, and after having done so it concluded that in this case the convict could not benefit from the rule. In itself, the Linkletter judgment may not have been very important; but it opened up some new ways of thinking. After 1965, the non-retroactivity concept has been gradually expanded to many major changes of criminal procedure which the Supreme Court brought about on the basis of the Bill of Rights; it was also applied to some other judicial rulings. ${ }^{11}$ This case law, in its turn, gave rise to many comments in American law reviews, purporting to look for "the Linkletter rationale." Notes on Defrenne often refer to the body of doctrine which is taking shape in the United States. ${ }^{12}$

Before actually looking into the difficulties which the concept of prospectivity involves, we shall try to distinguish it from two com-

5 Amendm. IV, U.S. Constitution.

9 Amendm. XIV, s. 1, U.S. Constitution.

In Justices Harlan, Frankfurter and Whittaker dissenting.

11 For example, Chevron Oil Co. v. Huson. 404 U.S. 97 (1971).

12 For example, Walter van Gerven, "Contribution de l'arrêt Defrenne au développement du droit communautaire," 13 Cah.Dr.Eur. 131 (1977). 
parable but not quite similar notions. The first of these is the case of purely " admonitory" functions of courts: the court, for instance a constitutional court, raises grave doubts about the constitutionality of certain legislation, and it exhorts the legislature to reform the law in order to make it compatible with the constitution. ${ }^{13}$ Legislative bodies may then enact new measures, either with retroactive effect or ex nunc, as they think fit; if they fail to act, they run the risk of having the old legislation struck down as unconstitutional. No prospectivity problem arises for the admonishing court, as its decision does not make any change in the law, but only enjoins others to do so. ${ }^{14}$ The second comparable but dissimilar problem concerns the legal effects of acts annulled by a court; it arises for courts exercising powers of judicial review of legislation or of administrative acts. Annulment is, of course, the very power of the court to rule about the past: it is retroactive by definition. However, the effects of annulment are often mitigated by particular constitutional or legal rules; thus, Article 174 of the E.E.C. Treaty provides that the Court of Justice, in case of annulment of a regulation, may declare which effects of the annulled regulation shall remain in force. It is especially in Austrian constitutional law that this system of " mitigated annulment" has been developed. ${ }^{15}$ Here, the situation comes very close to that covered by the prospectivity debate, but there are two important differences: the characteristic of a novel interpretation is not necessarily that it should be retrospective by its very nature (in fact, this is part of the debate); and normally, there are no legal provisions to settle this problem. As the American Supreme Court said in the Linkletter case, the Constitution "neither prohibits nor requires" retrospective effect; and the two European courts had to tread on virgin ground in Defrenne and Marckx. On the contrary, the purpose of annulment is to "erase the past." I agree with those authors who submit that reasons of legal certainty underlie provisions on the courts' powers to uphold certain results of the annulled act, and that these same reasons give rise to case law on prospective application of novel interpretations of the existing law ${ }^{16}$; but when they

13 See for Germany: BVerfGE 16, 130 (1963) on reapportionment; for Italy: Corte costituzionale no. 8, 2 June 1956, 1 Giur.costit. 602, on powers of prefetti.

14 See Rupp-von Brünneck, Vigoriti and Linde, "Admonitory functions of constitutional courts," 20 Am.Jn.Comp.Law 387 (1972).

15 See Mauro Cappelletti, Judicial review in the contemporary world (Indianapolis 1971), pp. 88 et seg.

16 Jean-Victor Louis, Lohngleichheit vor dem Gericht der Europäischen Gemeinschaften, Eur. Grundr. Zeitung 1976/178; H. Kutscher, Méthodes d'interprétation vues par un juge à la Cour (Rencontre judiciaire et universitaire 27-28 septembre 1976, Luxembourg 1976), p. I-42/45. 
conclude that therefore the problem is identical, I respectfully disagree. ${ }^{17}$

\section{When to Apply Prospectivity?}

Before analysing and assessing the arguments for and against retrospectivity, we shall have to devote some of our attention to a more empirical problem: when do courts apply prospectivity, i.e., what conditions are to be met before judges feel an urge to proclaim prospective application of their rulings?

Before prospectivity can even be considered, it must be clear that the decision is not just a further extension of existing case law, but that it really embarks upon a new course. There should be a "clear break with the past," as the American Supreme Court sometimes puts it ${ }^{18}$; and Mapp v. Ohio is often quoted as one of the most outstanding examples of such a break. The "clear break" is easy to see in the Marckx case. "Evolution towards equality has been slow," says the Human Rights Court, "and reliance on the Convention to accelerate this evolution was apparently contemplated at a rather late stage "; and it recalls that only twelve years earlier a similar complaint had been rejected by the European Commission on Human Rights as manifestly ill-founded. It is more difficult to discern the "break" in Defrenne. In that case, the reasoning of the Court of Justice seems to imply that its decision follows logically from its earlier case law on direct effect of Treaty provisions. If the Court really thought so, it may have overstated its case. It is true that there was an important body of case law on the direct effect of Treaty provisions which only impose obligations on the Member States, but which do so in such a way that the result to be achieved is clearly and unconditionally fixed, e.g., on admission of advocates ${ }^{19}$; but it is also true to say that these cases dealt with different situations: there, a citizen invoked the direct effect of the Treaty provisions vis-à-vis an institution of the Member State whose obligations were thus clearly and unconditionally determined, whilst in Defrenne the direct effect had to do with a situation in the field of private law, of employee against employer. ${ }^{20}$ So, there may be a "clear break," but the judgment itself is silent on it, and only implicitly admits it when considering the question of the " temporal effect."

This ambiguity in Defrenne may not merely be due to accident.

17 See also Alphonse Kohl. "Observations sur la 'non-rétroactivité' de l'autorité de l'arrêt Defrenne," 31 Rev.crit.jurispr.belge 231 (1977).

18 See Desist v. United States, 394 U.S. 244 (1969).

19 Case 2/74, Reyners [1974] E.C.R. 631.

20 See also C. J. Hamson, "Methods of interpretation, a critical assessment of the resulis" (Judicial and Academic Conference 27-28 September 1976, Luxembourg 1976), p. I-17. 
If the ruling on direct effect of Article 119 actually was a logical consequence of earlier case law, there would be little ground for not applying it retrospectively: workers, unions and corporations should have known, in that case, that the "direct-effect-doctrine" would also be applied to Article 119. If, in such a case, earlier decisions would not have clearly announced what the next step in the evolution of that doctrine would be, they would at least have "foreshadowed" this step. However, if we pursue the matter somewhat further in this direction, we discover a kind of logical problem in this field: it would not be unreasonable, at first sight, to say that only one of two possibilities can exist-either earlier case law gives some indication on the new course to be followed, or the new course is not foreshadowed at all; in the latter case it is difficult to see how a court could possibly come to its new interpretation (is a court doing what it ought to do, when its interpretation is so brand-new that no simple sign of it can be found in its earlier decisions?), but in the first case, it is as difficult to imagine how citizens could possibly rely on the older case law (they might have known better ...). When we put the problem in these abstract terms, we are, therefore, bound to deny any necessity of prospective application: either the courts reform after having foreshadowed, and retrospectivity is in order, or they don't foreshadow, but then they should stick to the line of their earlier case law. Unhappily, most legal problems resist being defined away in this manner; there is, of course, a "large murky area" between continuing an established interpretation and making a clear break with the past. ${ }^{21}$

Nevertheless, our logical problem represents something more than just a play of words. So much is obvious when we turn to the second condition which is generally regarded as necessary for applying prospectivity: citizens must have been relying on the law as it was interpreted previously. As an American author, Paul Mishkin, puts it: the only possible " rationale" for prospective application is that " retroactivity might unjustly inflict harm on those who justifiably relied on pre-existing authority." ${ }^{22}$ This formula, attractive and simple though it may seem, raises three far from easy questions: when can one say that people have "relied" on pre-existing authority; and when is such reliance " justifiable"; and finally-of course - can reliance ever be justifiable if the new decision was foreshadowed?

The problem of "reliance" is illustrated by the Linkletter case.

21 I borrow the term in quotation marks from Francis $X$. Beytagh, "Ten years of non-retroactivity, a critique and a proposal" 61 Virginia Law Rev. 1557 (1975).

22 Paul J. Mishkin, "The High Court, the great writ and the due process of time and law" 79 Harv.L.Rev.56 (1965). 
The petitioner had been prosecuted under state law, and his conviction had become final before Mapp was decided: whose reliance is then to be taken into account? The state prosecutor may have thought that he was right, the prison commissioners may have believed that they could lawfully detain the convict-but the convict himself, though probably not aware of the subsequent change of the law, may have believed that injustice had been done to him as he went to prison on the basis of evidence which had been obtained irregularly. Particularly in criminal cases, the notion of reliance is one of difficult application.

Should reliance always be " justifiable"? In Defrenne, the Court of Justice seemed to think that reliance had not been entirely justifiable:

However, in the light of the conduct of several of the Member States and the views adopted by the Commission and repeatedly brought to the notice of the circles concerned, it is appropriate to take exceptionally into account the fact that, over a prolonged period, the parties concerned have been led to continue with practices which were contrary to Article 119, although not yet prohibited under their national law.

The fact that, in spite of the warnings given, the Commission did not initiate proceedings under Article 169 against the Member States concerned on grounds of failure to fulfil an obligation was likely to consolidate the incorrect impression as to the effects of Article 119.

There is some reproach in this part of the reasoning: the citizens have been led to believe that Member States and the Commission knew what the law was (they should have known better, poor things). On the other hand, the text has obviously been drafted in a most careful way (" take exceptionally into account . . . ," "over a prolonged period ... ," etc.), and it is easy to see why. Without these qualifying terms, the judgment might be interpreted as meaning that non-compliance with Treaty provisions could give a certain advantage, in so far that a non-complying Member State might be able to postpone the full effect of a certain rule to a later date. Some Member States, perhaps most, would probably like such a delay sometimes, though not all of them for the same subject-matter (some for mutton, some for fish). The Court of Justice, it appears, was conscious of this risk when it formulated its judgment. Nevertheless, the text has been drafted in such a way as to avoid the question whether reliance on the behaviour of the Member States and of the Commission was justifiable. In this respect, the Marckx judgment is more in conformity with Mishkin's standards: it also complains that "a large number of Contracting States" have "for many 
years" regarded discrimination of illegitimate children "as permissible and normal," but its opinion that such a discrimination constitutes a violation of the Human Rights Convention is not founded on the inner logic of the Convention itself, but on the " evolution towards equality," dubbed as "slow"-all of which seems to imply that citizens and authorities could reasonably and justifiably believe that this particular form of discrimination might still last for some time.

We devoted already some attention to the problem whether reliance can ever be justifiable if the new decision was foreshadowed. Suffice it to repeat here that it will be hard to find judicial decisions which are not foreshadowed at all; normally, case law is something which is gradually evolving, and even major breaks may be announced in one way or another. But if the break is foreshadowed, citizens might know that it would be unwise to put too much trust on previous decisions. It seems, after all, a matter of degree.

The third condition for applying prospectivity has to do with the consequences which might result from retroactive application of the new interpretation. In Linkletter and similar cases, retroactive application of the Mapp rule might have had a "disruptive effect" on a good administration of justice: it might have resulted in a kind of judicial amnesty for all prisoners convicted on the basis of evidence obtained in an irregular way. Such a "general opening of prison doors" would indeed go very far. To take another example: in 1972, the U.S. Supreme Court considered (or at least seemed to consider) capital punishment as " cruel and unusual," and therefore forbidden by the federal Constitution ${ }^{23}$; if this new rule would have been made to act with full retrospectivity, the American penitentiary system would have been shaken in its foundations (the resulting crisis would have been the more acute as the Supreme Court overruled its 1972 decision some years later). The disruptive effect was probably also at the back of the Human Rights Court's mind in the Marckx case: it would require some imagination to predict what retroactive application might have done to, for instance, vested rights in estate, many years after the succession. Here also, one could speak of disruption of a good administration of justice. Again the Defrenne judgment is somewhat less explicit :

The Governments of Ireland and of the United Kingdom have drawn the Court's attention to the possible economic consequences of attributing direct effect to the provisions of Article 119 , on the ground that such a decision might, in many branches of economic life, result in the introduction of claims dating back to the time at which such effect came into existence. 
In view of the large number of people concerned, such claims, which undertakings could not have foreseen, might seriously affect the financial situation of such undertakings and even drive some of them to bankruptcy.

Are these risks to be considered as a disruptive effect of retrospective application of the judgment? One could have some doubts: sudden wage increases may also result from a massive strike; more generally, they may be viewed as belonging to the normal risks of undertakings in economic life.

The three elements we discussed (clear break with the past; reliance on pre-existing law; disruptive effect of retrospectivity) seem to constitute the conditions which make courts resort to prospective application. American literature often adds a fourth element: the "purpose" to be served by the new ruling ${ }^{24}$; some Supreme Court decisions also refer to it. ${ }^{25}$ The court applied it, for example, when it established new rules for the composition of juries in capital cases: it rejected a plea for prospectivity, in spite of considerations of reliance and effect, because improper jury-selection standards were likely to undermine the integrity of the guilt-determining process. ${ }^{26}$ It is hard to see, however, why a similar argument would not be valid in the Linkletter case. And this, to my mind, illustrates the difficulty: the "purpose" argument cuts both ways. If the purpose of the new ruling is so important that it represents a break with the past, and therefore justifies prospectivity, the same importance will in most cases form an argument for applying the new ruling equally, i.e., to everybody, and therefore retrospectively. Take Mapp or Defrenne: their originality from a legal point of view, their social impact, and the ends they serve, make together the result that their influence will be felt throughout society; and that is an argument for prospectivity in so far as this influence may be disrupting, but an argument for retrospectivity in so far as the importance of that influence is liable to make unequal treatment of cases having arisen before or after a certain date a most unlucky device. ${ }^{27}$

From this point of view, it seems scarcely possible to find a satisfactory solution. A fictitious example may illustrate these doubts: let us assume that a constitutional court, or the European Court of Human Rights, will hold that any form of imprisonment

24 See Francis Beytagh, op. cit., supra, note 21 ; Harry H. Wellington, "Common law rules and constitutional double standards: some notes on adjudication" 83 Yale L.J. 221 (1973).

25 Witherspoon v. Illinois, 391 U.S. 510 (1968); Desist v. United States, 394 U.S. 244 (1969).

26 In Witherspoon, note 25.

2: Van Gerven, op. cit., supra, note 12 accepts the "purpose" test for European law. 
is a " cruel and unusual" or " inhuman or degrading" punishment, and therefore forbidden. ${ }^{28}$ Such a ruling cannot mean that prison doors will be opened immediately, for if the sentencing court would have known that imprisonment was illegal, it would have imposed other penalties, like a fine. Nevertheless, keeping convicts in gaol after the court's new ruling will hardly do: a refusal to give relief retroactively to prisoners serving a "cruel " or " inhuman " sentence would be most unsatisfactory, for what the court's new ruling comes down to is that keeping people in gaol is contrary to human dignity. Only those who are opposed to any form of prospectivity have a clear answer to this problem: it highlights, they argue, the inherent weakness of the prospectivity doctrine. They will maintain that only legislative measures can bring relief in cases like this; that only legislative and administrative bodies are in a position to put some form of punishment in the place of prison for those who are already serving their sentence; and that therefore courts overstep the boundaries of their jurisdiction when they resort to law-giving by way of interpretation.

\section{The Argument Against Prospectivity}

The main argument against prospective application is indeed that it "smacks of the legislative process". ${ }^{29}$ It is up to the legislature, the argument runs, to introduce new rules of law; in doing so, it can take care of problems of transition from the old law to the newit will try to balance the disadvantages of imposing new rules to everybody, whatever his rights or expectations, with those of delaying a change of law which is desirable, or even, perhaps, overdue. $^{30}$ The courts, on the contrary, "find and declare" the law, i.e., the existing law. This maxim holds good even if the courts find an application of the law which nobody else had foreseen: their superior knowledge of the law has the effect that citizens accept that the law has always been as the courts say it is. This is what I shall call the Blackstonian concept-but I might as well call it Montesquivian, or Madisonian.

Is that concept out of date? Since Gény's works on methods of intepretation, one might say, we know better. ${ }^{31}$ Nearly a century of legal thinking taught us to be suspicious of strict demarcation lines between the areas of law-giving and of law-finding. Accustomed

28 A most unlikely hypothesis: see Art. 2, par. 1, and Art. 4, par. 1, Eur. Convention on Human Rights.

29 The term is Mishkin's: op. cit., supra, note 22.

30 See also O. Stocker op. cit., supra, note 2.

s1 The first edition of Gény's Méthodes d'interprétation et sources en droit privé positif was published in 1899 . 
as we are to looking at what judges " really" do, and not at what they are supposed to do according to eighteenth or nineteenth century precepts, we tend to see much resemblance between, for example, the process of defining a new tort in a statute and that of extending one of the old tort notions in a judgment. Accordingly, we are rather inclined to think that legislative and judicial activities have a certain area in common. Modern authors on the law-finding process, like Larenz and Esser in Germany, ${ }^{32}$ give a picture of judicial work which comes very close to what early nineteenth century commentators would have labelled as typical of legislative work. And it is easy to pile up allusions that all point in the same direction: one could think of the doctrine, once popular in the United States, that law is "what the courts say it is," of the sociological schools of jurisprudence, of the rebirth of the natural law tradition on the European continent, of the thesis of the "Richterstaat" (or " judicial state") in the German-speaking world, etc. To this whole panoply of learned opinion we can add something else: empirical studies on what judges do in fact when they decide a case, as well as a fairly general development in actual case law towards a somewhat more "activist" stand of the courts, confirm this evolution. Consequently, there can be scarcely any doubt left : the Blackstonian concept rests on a myth.

This conclusion, however, does not make an end to the debate. According to some authors, the concept may be unrealistic, but it has the merit of expressing a symbolic idea of the judicial process on which much of the courts' prestige and power depends. ${ }^{33}$ In other words: it may be a myth, but it is one by which we live. This argument cannot lightly be disposed of. Judicial decisions are not backed by the authority of popular election, by the force of arms, or by well-organised propaganda campaigns, as political decisions often are; but they rely on a moral force, which is none other than their submission to the law as it is, and not to the law as some may hope that it will become. For revolutionising the law, we can elect representatives, hold demonstrations, submit petitions, or organise hunger strikes; for keeping the law we instituted the judiciary. To see the force of this argument, one should keep in mind the fate of unpopular judicial decisions: they can only claim acceptance if those who are to obey are convinced that these decisions reflect the law, and not just the political or moral opinions of nine, five or three " old men" (to quote Franklin D. Roosevelt's invective). The Court of Justice

32 A summary, with many references to German literature, in Karl Engisch, "Einführung in das juristische Denken" (Urban Taschenbücher no. 80; 1st ed. Stuttgart 1956).

33 See particularly Mishkin, op. cit., supra, note 22. 
of the European Communities has some experience with this difficulty, as one of its rulings on the Euratom Treaty led to some wrathful debates, and even to charges of "politicking," in the French Parliament. ${ }^{34}$

I find this a very difficult question: should an out-dated theory be propagated, only because it is useful? It would be too machiavellian. However, there may be a way out. Perhaps, the abyss between the "realistic" or "modern" approach to the nature of judicial activities and that of the neo-Blackstonians is not as wide as it appears at first sight. If we refer to the law as something the courts should be faithful to, we are not only referring to rules of law which legislative action has brought into the statute book, but also to those principles which form the backbone of the law, and which have performed this same function over the centuries. No Blackstonian would be easily willing to deny that "being faithful to the law" implies being faithful to such principles. The crux of our problem is then that old principles will have to be applied to new and unforeseen situations; and in the process, they may take a shape they had never shown before. It is this type of adjustment which brings us into the area where legislative and judicial activities come very close: principles of law may be actualised by a statute, but also by a court of law. Recent history of the principle of equal protection, particularly in the United States and the Federal Republic of Germany, provides abundant material in that sense; it shows a large area of "concurrent" legislative and judicial activities. In the United States, the late fifties and early sixties showed a combined effort by the federal courts and the federal legislature to give substance to the principle of equal protection in the field of race relations. The Supreme Court took the lead; and it could do so because its decisions were anchored in constitutional principles. ${ }^{35}$ New law framed by the courts has all the moral force of old law, when it is firmly rooted in ancient principles which have been, and still are, the very foundations of the rule of law.

When we look at the problem of prospectivity from this perspective, we have to admit that it cannot be simplified into a mere question of observing the boundaries between the legislative and the judicial area; it is more complex than that. It is perhaps useful to recall that it was the very old principle of equal protection which was at the root of the Marckx case, as well as of Defrenne. The

34 Opinion 1/78, Draft Convention on nuclear installations (1978) E.C.R. 2151. See also debates on parliamentary questions put by Mr. Michel Debré, Compterendu des débats de l'Assemblée Nationale de 1 er juin 1979 et du 12 octobre 1979, Journal Officiel 1979 p. 4607-4611 and p. 8209-8212.

35 See Louis Lusky, "By what right?" (Charlottesville Va. 1975), Chap. XIII. 
Human Rights Court expressly refers to it, adding that it has to be interpreted "in the light of present-day conditions." 36

We can be brief as far as a second argument against any form of prospective ruling is concerned. It is sometimes argued that the courts, if empowered to limit the effects of their decisions to the future, will be encouraged to ordain sweeping changes of the law: as the immediate consequences of their boldness can be mitigated, they will not be hampered by practical considerations (the "freewheeling" argument). ${ }^{37}$ There is no evidence in support of this argument: Mapp, for example, was decided without expressing any thought about its temporal effect, and the same applies to many of the more daring judgments of the American Supreme Court, like the school cases, the reapportionment cases, etc. As far as the law of the European Communities is concerned, it seems most unlikely that the freewheeling argument could have played a role: Defrenne certainly is an important judgment, but there are other decisions by the Court of Justice which show a greater amount of judicial imagination, or which have had more important social consequences. Retrospectivity is not necessarily a bar to far-reaching or imaginative judgments.

\section{Forms of Prospectivity}

Before summing up our conclusions, we shall have to look into one other aspect of our problem, the different ways of softening retrospective effects.

In Marckx, the effects of the judgment are entirely limited to the future-there is no single element of retrospectivity. It is obvious that this solution of "pure prospectivity" presents the double advantage of protecting legal certainty without encroaching on equal treatment of all citizens; it does, indeed, something like introducing a new law. Those for whom the equality principle presents the most decisive standard of justice will therefore, in general, favour pure prospectivity. As an American Supreme Court judge, Mr. Justice Douglas, put it: “. . . even-handed justice requires either prospectivity only or complete retroactivity." ${ }^{38}$ It is quite as obvious, though, that pure prospectivity has one major inconvenience: it discourages citizens from challenging existing practice. Nobody but a professor of law likes to litigate for the sheer pleasure of it, and there is no incentive if the litigant cannot benefit from the decision

26 The case of the Human Rights Court is somewhat particular, as the Convention does not create rule-giving bodies; reference to "legislative" acts in that case must be taken to mean amendments to the Convention, e.g., by additional Protocol.

3: See Justice Harlan, concurring, in Mackey v. United States, 401 U.S. 667 (1971).

38 Justice Douglas, dissenting, in Adams v. Illinois, 405 U.S. 278 (1972). 
he was able to obtain. The result of pure prospectivity is, therefore, somewhat paradoxical: as the function of the courts is not to rule but to adjudicate, it seems odd that courts should be allowed to establish a new interpretation without applying it to the plaintiff who raised the problem. For some courts, this paradox may not have a great importance; one could think in particular of the Human Rights Court, whose " adjudicating" functions are of a very special kind. ${ }^{30}$ It has all the characteristics of an international court, which declares whether certain acts of the states subject to its jurisdiction are in conformity with the Convention it is intended to interpret. The American courts are at the other end of the scale, as the federal Constitution expressly provides that their power extends to "cases or controversies." ${ }^{40}$ In this respect, the Court of Justice of the European Communities holds an intermediate position: it may, for example, first act more or less as an international court when it condemns, on the basis of Article 169 of the E.E.C. Treaty, a Member State for having levied internal duties which were forbidden by the Treaty ${ }^{41}$; but at a later stage, it may then have to solve some real "case or controversy", if a business enterprise tries to recover duties unduly paid before the date of the Court's decision, and if a national court refers the matter to the Court of Justice under Article 177 of the Treaty. ${ }^{42}$ In the light of these considerations, the relative ease which guided the Human Rights Court in adopting pure prospectivity may be explained.

The real difficulty is that other forms of prospectivity may do more justice to the idea of "adjudication" by the courts, but that they run unavoidably into problems concerning equal treatment of citizens. If one compares Mapp to Linkletter, one gets the somewhat bitter impression that the accident decides who is to remain in prison. Defrenne is more subtle: it did not limit the retrospective effect of the decision to the case at hand, but it extended that effect to all cases that were pending at the date of the judgment. That means that the prospective effect of the Court's holding could only be opposed to those who had taken no initiative to defend their rights. This choice does not discourage litigants from challenging illegal situations, and it could also be based on the old maxim "ius vigilantibus scriptum." Nevertheless, chance may have decided whether a female worker brought her action for equal pay during the week before or after the Defrenne judgment; thus, the Court of Justice

39 See Art. 50 Eur. Convention on Human Rights.

10 Art. III, s. 2, U.S. Constitution.

41 See Art. 95 E.E.C.

42 See for example case 33/76, Rewe Zentralfinanz (1976) E.C.R. 1989. 
has not been able to eliminate the problem of what the American Supreme Court calls that of the "chance beneficiaries." ${ }^{43}$

One could very well imagine other techniques of defining categories that are allowed to benefit from a limited retrospective effect, according to the nature of the new rule to be introduced. In matters of income tax-normally levied on an annual basisit will be easier to find a clear dividing line than in matters of contract or of criminal procedure. But whatever one is able to find out, one will always have to allow for some element of chance.

\section{Conclusions}

Two main conclusions seem to result from the foregoing considerations.

The first is that the practice of giving prospective effect to new case law is not necessarily an indication that the courts trespass upon areas traditionally reserved to legislative authorities. As Defrenne and Marckx convincingly demonstrate, some parts of the law are in movement although they are governed by principles of law which form part and parcel of legal tradition-in the case of the European courts of a common legal tradition. American experience suggests that old principles may, in the hands of the courts, produce surprisingly new solutions to legal problems: the considerable body of American case law on equal protection may reflect " the aspirations and divisions of contemporary society," and it may have revolutionised American law, but it has also had the effect of giving finally some kind of meaning to the "equal protection" clause of the XIVth Amendment to the American Constitution, somewhat less than a century after it had come into force. ${ }^{44}$ It is quite possible that the development of European law has comparable surprises in store. Courts and legislatures should concur in framing legal principles in such a way that our legal systems can grapple with the social problems of our day. In some fields of the law, it is difficult to see how it could be otherwise. In the framework of the common agricultural policy, for example, where assessments of similarity or comparability have to be made in complicated economic situations, the Council of the E.E.C. and the Court of Justice will jointly contribute to the process of giving shape to non-discrimination principles ${ }^{45}$; they simply have no other choice. It is a trite observation

43 See Stovall v. Denno, 388 U.S. 293 (1967).

44 Archibald Cox, The role of the Supreme Court in American Government (Oxford 1976), Chap. III.

15 See joint cases 124/76 and 20/77, Moulins et Huileries de Pont-à-Mousson (" gritz de mais") (1977) E.C.R. 1795. 
that courts and legislative bodies will achieve their contributions in their own different ways; but prospectivity is not necessarily part of these differences. If courts can open new avenues by interpreting legal principles, and if they are thus in a position to render judgments with great social impact, they should evidently be aware of the consequences of what they are doing. 'The retrospectivityprospectivity debate concerns these consequences.

The second conclusion is less reassuring: there is no way of defining a set of criteria that would enable the courts to make their choice between retrospective and prospective application on the basis of fixed standards, and with a clear conscience. On every single occasion they will have to strike the balance between legal certainty on the one hand and equal protection on the other. In principle, every reform of the law, whether judge-made or not, is liable to bring harm to legal certainty, to disappoint people who placed their trust in the law as they used to know it; and the efforts which have been made to distinguish between "justifiable" and " unjustifiable" forms of reliance seem to have failed. In coping with this difficulty, legislative bodies can avail themselves of a great variety of methods which are not, or not always, open to the courts: they can, for example, when refusing a certain advantage to persons who believed they were entitled to it, substitute a different advantage. One of the sole things a court can do in such a case is to limit the effects of its ruling, i.e., to soften the consequences of retrospective application. However, in doing so it will either have to disappoint the petitioner who was right, by making an option in favour of pure prospectivity (and this is always a difficult thing to do for a court), or to make a distinction between some people who benefit from the legal reform and others who do not, because they have been too slow, or come too late. Consequently, limiting retrospective effects will always mean one of two evils: failing to adjudicate the conflict submitted to the court, or adjudicating it in such a way that the result is inherently in contradiction with equal protection. The graver this judicial violation of equality will seem to the judge, the more he will be inclined to sacrifice legal certainty, rather than equal treatment.

In the last analysis, it would seem that retrospectivity is rightly considered as the normal system for judicial rulings. For most courts, though not for special courts such as the Human Rights Court, pure prospectivity would be too far removed from what they consider as their essential function: rendering justice in a conflict between two parties. Every more limited form of softening the effects of retrospectivity will, however, compel the courts to appreciate whether upholding citizens' interests in legal certainty will not unduly downgrade the 
principle of equality before the law. They will have to choose, in every case in issue, which of the two evils is worse.

This conclusion may sound somewhat disappointing to those who like clear-cut solutions to legal problems. Perhaps, some parts of the law are not yet sufficiently charted to permit straight sailing. It is also possible, however, that "the variety of controversies which grow out of the folly and wickedness of mankind," Hamilton's explanation for the "laboriousness" of the law, ${ }^{46}$ can also help to explain why clear solutions are not always good solutions. 